\title{
SELECTED METHODS OF MEASURING WORKLOAD AMONG INTENSIVE CARE NURSING STAFF
}

\section{KATARZYNA KWIECIEŃ ${ }^{1,2}$, MARIA WUJTEWICZ ${ }^{1}$, and WIOLETTA MĘDRZYCKA-DABBROWSKA²}

${ }^{1}$ Medical University of Gdańsk, Gdańsk, Poland

Clinic of Anesthesiology and Intensive Therapy

${ }^{2}$ Medical University of Gdańsk, Gdańsk, Poland

Department of General Nursing

\begin{abstract}
Intensive care units and well-qualified medical staff are indispensable for the proper functioning of every hospital facility. Due to demographic changes and technological progress having extended the average life expectancy, the number of patients hospitalized in intensive care units increases every year $[9,10]$. Global shortages of nursing staff (including changes in their age structure) have triggered a debate on the working environment and workload the nursing staff are exposed to while performing their duties. This paper provides a critical review of selected methods for the measurement of the workload of intensive care nurses and points out their practical uses. The paper reviews Polish and foreign literature on workload and the measurement tools used to evaluate workload indicators.
\end{abstract}

Key words:

Workload, Workload measurement tools, Intensive care nurses, Intensive care unit

\section{INTRODUCTION}

The work environment of nursing staff has changed significantly over the last few years. This has resulted from health care system reforms, hospital restructuring, costcutting and considerable shortages of nursing staff $[1,2]$. Due to rapid technological progress and high expectations of patients with respect to the quality of treatment and care, the work environment has become one of the most frequently mentioned stress factors in daily nursing practice $[1,3]$.

Previous studies in intensive care units have ensured a preliminary evaluation of nursing staff workload. They have also served as a foundation for further research of workload-related issues [4]. In practice, workload measurement is extremely difficult to carry out. This is due to the fact that the work performed by nursing staff is not classed as productive work. Its focus is to influence the living organism. Hence, the effects of nurses' work are to be considered exclusively in qualitative terms [5].

The issue of nursing staff workload is relatively little known. No unambiguous definition of workload can be found in the literature on the subject. And yet, it is a factor of considerable significance for the bio-psycho-social functioning of an employee [6]. An increase in workload not only leads to increased absence from work [7], but it is also one of the key factors determining the decision to withdraw from the professional life or change the employment profile [8].

Received: December 2, 2012. Accepted: April 11, 2012

Address reprint request to K. Kwiecień, Clinic of Anesthesiology and Intensive Therapy, Medical University of Gdańsk, Dębinki 7, 80-211 Gdańsk, Poland (e-mail: kasiad124@gumed.edu.pl). 
This paper provides a critical review of selected methods for the measurement of workload of intensive care nurses and points out their practical uses. The paper reviews Polish and foreign literature concerning workload and the measurement tools used to evaluate workload indicators.

\section{Intensive Care Unit Work Environment}

Intensive care units, as well as well-qualified medical staff, are indispensable for the proper functioning of every hospital facility. According to statistical data, more and more patients are hospitalized in intensive care units every year. This is associated not only with demographic changes and the ageing of the population, but also with technological progress making it possible to prolong the average life expectancy $[9,10]$. Most of the patients hospitalized in an intensive care unit are in a life-threatening condition [11]. These patients often require prolonged artificial ventilation by means of a respirator and infusions of vasoactive medications, antibiotics or diuretics. The physician's role in the therapeutic process is indisputable; however, we should remember that most activities by a patient's bed are performed by nursing staff [12]. The increased demand for nursing care can intensify the feeling of being under strain and tired of work.

Regrettably, the increased demand for intensive care services is disproportionate to the actual number of beds available in intensive care units. In most European countries, they constitute approx. 8-10\% of the overall number of hospital beds [13]. In Poland, their level is governed by the Regulations of the Minister of Health and Social Policy of 27 February 1998. According to these guidelines, the number of beds in an intensive care unit should not exceed $2-5 \%$ of the overall number of beds in a hospital [14]. Irrespective of the type of medical facility, the common feature of every intensive care unit is the work environment. According to many researchers, it is the key source of stress factors of physical, psychological and organizational nature. The most frequently noted factors include: bad lighting, noise, a large quantity of specialist medical equipment, too little room, high mortality of patients, inability to see the effects of work, disruptions in the inter-team communication, pressure and the necessity of quick decision-taking [1]. Many of the above conditions are evidenced in domestic projects. Rogala-Pawelczyk added another factor to the group of factors affecting the level of decreased satisfaction with work, namely the insufficient staffing level among nurses [15].

The presented components of the intensive care unit environment have not been exhausted to the full yet. Global shortages of qualified medical personnel have triggered a debate on the issues of workload concerning the nursing staff group. This is still a topical matter, as, what strikes us while observing the work of nurses in intensive care units or other surgical units is the immense distance between the progress in diagnostic and therapeutic methods and the workload nurses are exposed to while performing their job responsibilities.

\section{Why is Workload Measurement so Important?}

Workload is one of the most frequently quoted factors affecting the dissatisfaction of the nursing staff with their work [16]. A study conducted in 2007 among a group of operating theater nurses showed that more than $50 \%$ of the participants evaluated their work as quite hard. $12 \%$ of the respondents thought that the work they performed was hard [17]. The bulk of work duties, not always associated with direct patient care, influences the level of the provided medical services. Previous scientific reports point to a significant interrelationship between a decrease in the nursing staff workload and health benefits obtained during the patient's treatment. The observations conducted in surgical units, including intensive care units, distinctly point to a corelation between the workload of nursing staff and the severity of the patient's condition [4]. Although views on this matter are divided, some researchers claim that there are connections between the number of nurses and a decrease 
Table 1. Distribution of nurses* age in Poland [20]

\begin{tabular}{lcc}
\hline \multirow{2}{*}{$\begin{array}{c}\text { Age group } \\
\text { (years) }\end{array}$} & \multicolumn{2}{c}{ Nurses population } \\
\cline { 2 - 3 } & $\mathrm{n}$ & $\%$ \\
\hline $19-25$ & 10563 & 4.00 \\
$26-30$ & 27292 & 10.35 \\
$31-35$ & 46328 & 17.56 \\
$36-40$ & 47535 & 18.02 \\
$41-45$ & 46203 & 17.51 \\
$46-50$ & 42311 & 16.04 \\
$51-55$ & 28514 & 10.81 \\
$56-60$ & 12086 & 4.58 \\
$61-65$ & 2984 & 1.13 \\
\hline
\end{tabular}

* Nurses registred until 31 December 2009.

in the incidence of: catheter-related infections, pneumonias, bedsores and post-operative complications [18].

An age structure analysis leads to better understanding of the issue of workload among the nursing staff. The average age of nurses in Poland is 44-45. Most nurses, namely 48 601, are in the age range of 41-45 years (Table 1 ).

While examining the age structure, particular attention needs to be paid to the difference between the number of nurses aged 36-40 and the age ranges of 31-35 and 26-30. In each consecutive age range there are approximately 20 thousand fewer nurses than in the preceding one [19]. Preliminary estimates indicate that in 2012-2015 some 26743 nurses will disappear from the health care system. This is a significant number in comparison with the number of the newly employed nurses (some 1487 people/year on average) [20].

Considering the age structure of nurses in Poland and abroad, every strategy aimed at improving the working conditions, including reducing the workload, seems to be justified.

\section{Methods of Workload Measurement}

There are numerous definitions of nursing workload. Each of them focuses on different characteristics of workload. Some scientists believe that the term should refer to "the entirety of work" performed by nurses for their patients' benefit. Other definitions describe workload in terms of its intensity or the amount of effort related to it. Both terms are used interchangeably by both the leading nursing organizations and practitioners [5].

For the first time, the measurement of nursing workload began in 1970s because of the need for determining the severity of illnesses and cost - effectiveness in the intensive care units. In the following decades, the need for more specific tools for assessing nursing workload resulted in the development of new scoring systems [21].

The methods used in workload studies are usually based on the measurement of the intensity of work or the number of activities performed by the nursing staff for a patient within a specific time bracket. However, these are extremely limited tools, showing merely a fragment of the scale of the problem in the scope of workload. This is the reason why more and more researchers fall back on experimental methods allowing them to estimate the physical and psychological workload (tiredness) [5,22,23]. Tiredness is a typical physiological reaction to work. One of the most frequently used methods to analyze the phenomenon of tiredness is a subjective evaluation of its intensity [24]. O'Breien-Pallas, in his discussion of nursing workload, suggested that every research method was appropriate if it took into consideration such characteristics as: the patient's condition, the number of nursing interventions, the level of demand for nursing care and environmental factors [25].

A lot more studies on workload originate from Finland. Fargerström, quoted by Morris, thinks that a correct measurement of nursing workload is only possible if the numbers of human resources available are taken into consideration [5].

Different most popular methods of nursing workload measurement are presented below. The methods are used to identify the volume of effort, workload and the level of tiredness in nurses. 
Other available scoring systems, such as: OMEGA or TOSS-Time Oriented Score System, have not been mentioned because they are no longer used in clinical practice.

\section{Patient Classification}

\section{as a Method of Workload Measurement}

Patient classification is a system designed to group patients according to their degree of demand for nursing care. It is a tool that helps in the proper allocation of nursing staff in a unit according to the needs [26]. The patient classification system is based on a division of patients following the established criteria of care: mobility, personal hygiene, excretory functions, measurement of vital signs, treatment, communication and self-care ability. Each category is assigned a number of hours of care per day. Four categories of care are used in medical and surgical units:

- Category I - self-sufficient patient (36-32 pts) $30 \mathrm{~min} /$ day/patient,

- Category II - patient requiring assistance and stimulation (31-23 pts) - $60 \mathrm{~min} /$ day/patient,

- Category III - bedridden patient (22-14 pts) $90 \mathrm{~min} /$ day/patient,

- Category IV - patient requiring intensive care (13-9 pts) - $210 \mathrm{~min} /$ day/patient [27].

Intensive care units use three categories of nursing care and the number of minutes of direct care assigned to them (Table 2) [28].

Patient categorization makes it possible not only the properly utilize human resources, but -above all - to ensure the provision of quality nursing care [27].

In the world, there are several dozens of scale types used to classify patients in surgical units, including intensive therapy units. In Finland, the most popular scale is the fivegrade OPC scale. The results of the studies conducted in over 1737 patients using the OPC scale have shown a correlation between the level of workload and the age and sex of the nursing staff [26]. Other countries use scales evaluating patients' daily living activity to estimate the demand for nursing care and, indirectly, the degree of nursing workload, for instance the Katz Index of Independence in Activities of Daily Living (ADL) or the Barthel Index Scale [5].

\section{TISS-28 Scale}

\section{(Therapeutic Intervention Scoring System)}

The TISS-28 scale was created in 1996 on the basis of a primary 76 -item scale which was reduced to 28 therapeutic interventions divided into 7 groups. The tool has been tested in a dozen or so intensive care units at teaching and non-teaching hospitals [4,29]. The scores on the TISS-28 scale have been divided into four categories relating to the severity of the patients' condition, and consequently, the number of the necessary nursing staff. Based on numerous studies using the TISS scale, the time required to acquire one point during an 8-hour working shift was calculated. It was also calculated that a nurse should not acquire more than 46 points during one duty [30]. The studies conducted in domestic centers have demonstrated that the norm per one nurse is significantly exceeded. According to the authors, this could result from the differences in working systems or the lack of patient categorization. It was noted that one nurse often took care of two or three patients in grave condition during a day or night shift [4].

The TISS-28 scale is used to assess the amount of effort of nursing staff and the level of workload in intensive care units [4].

\section{Nine Equivalents of Nursing Manpower Use Score (NEMS)}

NEMS is a scale frequently used in intensive care units. It originated in 1994 on the basis of the TISS-28 scale. This scale includes 9 therapeutic interventions involving: vital signs monitoring, administration of intravenous medications, respiratory therapy and treatment using vasoactive medications or other specialist techniques. Statistical analyses have shown that NEMS correlates well with the scale on which it was based. NEMS is a good measuring 
Table 2. The classification of the ICU patients $[27,28]$

\begin{tabular}{|c|c|c|c|}
\hline Level of care & $\begin{array}{c}\text { Level I } \\
\text { 36-23 (score) } \\
186 \text { min/day/patient } \\
\text { (minimal level of care) }\end{array}$ & $\begin{array}{c}\text { Level II } \\
\text { 22-14 (score) } \\
294 \text { min/day/patient } \\
\text { (average level of care) }\end{array}$ & $\begin{array}{c}\text { Level III } \\
\text { 13-9 (sore) } \\
427 \text { min/day/patient } \\
\text { (high level of care) }\end{array}$ \\
\hline $\begin{array}{l}\text { Physical activity } \\
\text { (mobile) }\end{array}$ & patient fully mobile & $\begin{array}{l}\text { partial immobility, patient needs } \\
\text { help and support with walking or } \\
\text { getting up }\end{array}$ & $\begin{array}{l}\text { total immobility, patient requires a nurse } \\
\text { at the bedside continuously for } 24 \mathrm{~h} / \text { day, } \\
\text { very often patients during the first } 24 \mathrm{~h} \\
\text { after the operation }\end{array}$ \\
\hline Hygiene & $\begin{array}{l}\text { patient able to maintain } \\
\text { independent self-care }\end{array}$ & $\begin{array}{l}\text { partial loss of independent } \\
\text { selfcare; } \\
\text { patient needs support with } \\
\text { personal care (washing, dressing, } \\
\text { going to the toilet) }\end{array}$ & $\begin{array}{l}\text { patient requiring high level of support in } \\
\text { all aspects of personal care (changing of } \\
\text { the sheets, washing in bed, oral hygiene, } \\
\text { preventive care of bedsores) }\end{array}$ \\
\hline Feeding & patient is independent & $\begin{array}{l}\text { patient needs a little help with } \\
\text { grinding the meal }\end{array}$ & $\begin{array}{l}\text { patient requiring high level of support } \\
\text { with feeding, he or she is not able to eat } \\
\text { on his or her own, very often he or she has } \\
\text { nosogastric tube or PEG }\end{array}$ \\
\hline Elimination & $\begin{array}{l}\text { patient with normal } \\
\text { bowel/bladder control }\end{array}$ & $\begin{array}{l}\text { partial loss of bowel/bladder } \\
\text { control }\end{array}$ & $\begin{array}{l}\text { total loss of bowel/bladder function } \\
\text { (patient with Foley's catheter, nappies) }\end{array}$ \\
\hline $\begin{array}{l}\text { Airway, breathing and } \\
\text { circulation }(\mathrm{ABC})\end{array}$ & no / ABC problems & $\begin{array}{l}\text { risk of airway, breathing or } \\
\text { circulation impairment, or } \\
\text { potential to be in shock due to } \\
\text { the condition; parameters should } \\
\text { be measured more than } 2 \text { times } \\
\text { during a shift }\end{array}$ & $\begin{array}{l}\text { cardiac or respiratory arrest, or } \\
\text { risk of arrest, complete impairment } \\
\text { of } A B C \text { or shock, parameters must be } \\
\text { measured more than } 2 \text { times during the } \\
\text { shift, patient in such condition requires: } \\
\text { fast blood tests (more than } 2 \text { times } \\
\text { per shift), urine tests, water balance } \\
\text { assessment }\end{array}$ \\
\hline Medical treatments & $\begin{array}{l}\text { patient is able to perform } \\
\text { unassisted administration }\end{array}$ & $\begin{array}{l}\text { partially independent, needs } \\
\text { an } I V \text { and } I M \text { injections; wounds } \\
\text { dressing must be changed } \\
\text { minimum } 2 \text { times during a shift }\end{array}$ & $\begin{array}{l}\text { patient requires advanced medication } \\
\text { support, } I M \text { and } I V \text { injections, most } \\
\text { of the medication is delivered in pumps, } \\
\text { wounds dressing must be changed more } \\
\text { than } 2 \text { times during a shift }\end{array}$ \\
\hline $\begin{array}{l}\text { Education and } \\
\text { psychological support }\end{array}$ & $\begin{array}{l}\text { full knowledge of health } \\
\text { and illness, requires basic } \\
\text { information about the } \\
\text { department, (topography, } \\
\text { the day schedule, the } \\
\text { powers of the patient, } \\
\text { persons preparing for } \\
\text { planned care proceedings) } \\
\text { does not require } \\
\text { psychological support }\end{array}$ & $\begin{array}{l}\text { poor orientation in health } \\
\text { matters, requires information } \\
\text { about health and the disease, } \\
\text { as well as psychological support, } \\
\text { manifests a certain level of } \\
\text { anxiety, mood somewhat } \\
\text { worsened }\end{array}$ & $\begin{array}{l}\text { patient lacks the knowledge about health } \\
\text { and the disease, requires information and } \\
\text { psychological support, often manifests } \\
\text { high levels of anxiety, confused, depressed } \\
\text { mood, the patient's family should be } \\
\text { included in an educational and support } \\
\text { program }\end{array}$ \\
\hline
\end{tabular}

ICU - intensive care unit, PEG - percutaneus endoscopic gastrostomy tube.

$I V$ - intravenous, $I M$ - intramuscular. 
tool, and yet, when using it, one should remember that it does not take into account all the nursing activities performed for a patient, such as: care, administrative tasks, and education of the patient and family [4].

\section{Nursing Activities Score (NAS)}

Nursing Activities Score (NAS) also originated from the TISS-28 scale [31]. It was developed by Dutch researchers and published in "Critical Care Medicine" in 2003. NAS consists of interventions performed by or with the participation of a nurse while taking care of a patient hospitalized in an intensive care unit. It classifies 23 interventions into 5 groups of activities: those related to evaluating the patient's condition, therapeutic interventions, nursing interventions related to personal hygiene maintenance, patient rehabilitation and taking care of the family. Each group of activities has a specific score weight which constitutes the percentage of time required to perform them in relation to a 24-hour period [32]. The maximum possible score is $100 \%$ [31]. Using NAS it is possible to calculate the necessary staffing level, expressed as the nurse-patient ratio, i.e. number of nurses per number of patients [32]. Multi-center studies have confirmed the usefulness of the scale in the assessment of nursing workload in intensive care units. The correlations discovered using NAS and TISS-28 have shown a significant divergence of results, which in turn has cast doubt on the usefulness of TISS-28 as a measuring tool of the amount of effort and workload of nursing staff [31].

In Poland, this scale was first used in 2006. On the basis of the obtained results, the recommended level of nursing staff in an intensive care unit was estimated at 1:1.2 (nurse: patient) [32].

\section{Experimental Methods}

The research tools used more and more frequently to estimate the workload levels are experimental methods such as direct and indirect calorimetry devices. These methods measure the physical activity of an individual, thus assessing the level of energy expenditure during a work shift [33]. According to Szubert, expenditure of energy is the basic physiological indicator commonly used to assess workload [34].

Many methods been been invented for the assessment of an individual's physical activity. They are objective methods based on the energy expenditure criterion: direct calorimetry, indirect calorimetry and doubly labeled water, the use of the technical apparatuses: pedometers, accelerometers and pulsometers. The first type are methods using the metabolic criterion for the measurement, namely the level of oxygen intake and carbon dioxide or heat production. The second type of objective methods are indirect calorimetry methods in which special meters are used for the measurement of heart rate and movement (kinematic analysis). To conduct the kinematic analysis there are used electronic and mechanic movement tools, like: pedometers and accelerometers [33,35].

The operation of a pedometer is based on a pendulum detecting a person's body movements. Pedometers record the acceleration and deceleration of motion during movements, which is accompanied by waist movements [33].

An accelerometer is a tool which measures the physical activity and also inactivity. Such devices are easy to wear and do not influence the moving ability. They enable the researchers to measure the intensity, frequency and time of activity [33,35].

Previous experimental studies in scope of measuring nursing workload conducted in various surgical units, including intensive care units, used pedometers, Holter monitors and pulse meters $[22,23]$. The authors pointed to the problem of increased tiredness among nursing staff. They also demonstrated that the level of experienced tiredness was disproportionately high, compared to the number of steps taken or the amount of expended energy [23]. Studies led in 2006 and 2007 showed that bending, standing and walking are recognized as the typical physical activities 
among hospital nurses [36-38]. According to a number of time-devoted studies, the percentages of working time spent on weight-handling, bending, standing and walking among hospital nurses were $20-25 \%$ and $62-91 \%$, respectively $[37,39,40]$.

Another research related to energy expenditure and heart rate (HR) suggests that nursing workload of 12-hour shifts has a negative physiological impact on nurses. Considering the fact that over one-third of the nurses experienced average working HRs above $100 \mathrm{bpm}$ and a moderate cardiac stress level, the research has shown that hospital nurses may be at risk for cardiovascular disorders, especially if they are overweight or obese [41].

\section{CONCLUSIONS}

In the light of new scientific reports, the existing methods of measuring workload, aimed at estimating the amount of a nurse's effort, seem insufficient. The presented scales, namely TISS-28, NEMS and NAS, are limited to merely presenting the severity of a patient's condition and the number of nursing activities performed throughout a specific time range.

The "multidimensionality" of the issue of workload calls for new and more complex research methods to be sought. The commonly used physiological indicator of work, energy expenditure, should be extended to include scales for measuring the physical symptoms of tiredness and weariness.

\section{REFERENCES}

1. Alameddine M, Dainty KN, Deber R, Sibbald W. The intensive care unit work environment: Current challenges and recommendations for the future. J Crit Care 2009;24:243-8.

2. Biradzki M. Reform without reform. Men Zdr 2010;7:20-22 [in Polish].

3. Daravas JA, Hawkins LG. What makes a good intensive care unit: a nursing perspective. Aust Crit Care 2002;15(2):77-82.
4. Cudak-Bańska E, Dyk D, Zadroga M, Krysiak I, Gabryszczak M. Quantitative estimation of the intensive care nurse workload with the TISS-28 and NEMS. Med Intens Ratun 2005;8(3):137-43 [in Polish].

5. Morris R, Manceela PN, Scott A, Pearl T, Hyde A. Reconsidering the conceptualization of nursing workload: literature review. J Adv Nurs 2007;57(5):463-71.

6. Duffield C, Roche M, Merrick E. Methods of measuring nursing workload in Australia. Collegian 2006;13(1):16-22.

7. Unruh L, Lindell J, Strickland M. Nurse absenteeism and workload: negative effect on restraint use, incident reports and mortality. J Adv Nurs 2007;60(6):673-81.

8. Szubert Z, Sobala W. Some job factors associated with departure from working life before retirement age. Med Pr 2006:57(4):325-34.

9. Parker A, Wyatt R, Ridley S. Intensive care services; a crisis of increasing expressed demand. Anaesthesia 1998;53(2): $113-20$.

10. Bion JF, Bennet D. Epidemiology of intensive care medicine: supply versus demand. Br Med Bull 1999;5(1):2-11.

11. Nestorowicz A. Considerations on the condition of anaesthesiology and intensive therapy in our country. Nowa Med 1997;4(21):2-5 [in Polish].

12. Aitkenhead AR, Smith G, editors. Anesthesiology. Vol. 1 and 2. Poznań: Oficyna Wydawnicza Atena; 1996. p. 317,381 [in Polish].

13. Morgan GE, Mikihail MS, Murray MJ. Clinical Anesthesiology. 4th ed. New York: The McGraw-Hill Companies; 2006 [cited 2011 Nov 28]. Available from URL: http:/www.accessmedicine.com/content.aspx?aID $=895850$.

14. POLANEST. The Regulations of the Minister of Health and Social Policy of 27.02.1998 on the requirements to be met in terms of technical and sanitary facilities and equipment of health care. [cited 2011 Aug 25]. Available from URL: http://www.polanest.webd.pl/pliki/rozporz.html [in Polish].

15. Rogala-Pawelczyk G. Burnout syndrome in nursing workplaces in anesthesiology and intensive care units. IV Congress of the Polish Anesthesia and Intensive Care Nurses Association. 
Nursing in anesthesiology and intensive care medicine - the requirements, expectations and realities. 2005 June 2-4, Poznań, Poland. Poznań: Polish Anesthesia and Intensive Care Nurses Association; 2005. p. 33-9 [in Polish].

16. Aiken LH, Clarke SP, Sloane DP, Sochalski J, Busse R, Clarke H, et al. Nurses' Reports On Hospital Care In Five Countries. The ways in which nurses' work is structured have left nurses among the least satisfied workers, and the problem is getting worse. Health Aff 2001;20(3):43-53.

17. Kułagowska E. Working conditions in operating rooms. Med Pr 2007;58(1):1-5 [in Polish].

18. Dang D, Johantagen M, Pronovost P, Jenckes M, Bass E. Postoperative complications: Does the intensive care unit staff make a difference. Heart Lung 2002;31(3):219-28.

19. The Main Chamber of Nurses and Midwives. The initial evaluation of nursing and midwives staff in Poland until 2020. 2010 Jun [cited 2011 Aug 25]. Available from URL: http://www.izbapiel.org.pl/upload/Wstepna.ocena.zasobow. kadrowych.pdf [in Polish].

20. The Main Chamber of Nurses and Midwives. Analysis of nurses and midwives going into retirement and staff entering the health system. 2008 Nov [cited 2011 Aug 25]. Available from URL: http://www.izbapiel.org.pl/uploadf/raporty/Analiza_emerytura.pdf [in Polish].

21. Guccione A, Morena A, Pezzi A, Lapichino G. The assesment of nursing workload. Minerva Anestesiol 2004;70(5):411-6.

22. Irimagawa S, Imamiya S. Industrial hygienic study on nursing activities investigation on heart rate and energy expenditure of cranial nerves and ICU ward nurses. Kitasato Arch Exp Med 1993;65:91-8.

23. Irimagawa S, Imamiya S. Industrial Hygienic study of nursing activities comparison of energy expenditure between pedometer and holter electrocardiograph. Kitasato Arch Of Exp Med 1993;65:99-105.

24. Zysnarska M, Bernad D, Maksymiuk T, Adamek R, Kara I. Specific elements of nurse over load. Fam Med 2008;10(4):1351-5.
25. O'Brien-Pallas L, Baumann A. Toward evidence-based policy decisions: a case study of nursing health human resources in Ontario, Canada. Nurs Inquiry 2000;7(4):248-57.

26. Lungrén-Laine H, Souminem T. Nursing intensity and patient classification system at an adult intensive care unit (ICU). Intens Crit Care Nurs 2007;23:97-103.

27. The Main Chamber of Nurses and Midwives. Safe staffing safe lives. 2011 March [cited 2011 Aug 25]. Available from URL: http://www.oipip.zgora.pl/pdf/planowanieobsad-pielegniarskich.doc [in Polish].

28. Ksykiewicz-Dorota A. Planning for nursing staffs in stationary hospitals. Lublin: Wydawnictwo Czelej; 2001. p. 20,24,76 [in Polish].

29. Kiekas P, Brokalaki H, Manolis E, Samios A, Skartsani Ch, Baltopolus G. Patient severity as an indicator of nursing workload in the intensive care unit. Nurs Crit Care 2007;12(1): 34-41.

30. Miranda DR, Rijk A de, Schaufeli W. Simplified Therapeutic Intervention Scoring System. The TISS-28 items - results from a multicenter study. Crit Care Med 1997;24(1):64-73.

31. Padilha K, de Sousa R, Queijo AF, Mendes AM, Miranda DR. Nursing Activities Score in the intensive care unit: Analysis of the related factors. Intens Crit Care Nurs 2008;24: 197-204.

32. Dyk D, Cudak EK. Aplication of Nursing Activities Score for planning nurse staffing in intensive care units. Anestezjol Ratown 2008;1:70-5 [in Polish].

33. Lipert A, Jegier A. The measurement of physical activity. Med Sport 2009;3(6):155-68 [in Polish].

34. Szubert J, Szubert S, Bortkiewicz A. A new method for the determination of the human energy expenditure. Med Pr 2008;59(3):215-22 [in Polish].

35. Melanson EL Jr, Freedson PS. Physical Activity Assessment: A Review of Methods. Crit Rev Food Sci Nutr 1996;36(5): 385-96.

36. Welton JM, Decker M, Adam J, Zone-Smith J. How far do nurses walk? Med Surg Nurs 2006;15(4):213-6. 
37. Freitag S, Ellegast R, Dulon M, Nienhaus A. Quantitative measurement of stressful trunk postures in nursing professions. Ann Occup Hyg 2007;51(4):385-95.

38. Upeniekas VV, Kotlerman J, Akhavan J, Esser J, Nago MJ. Assessing nursing staffing ratios: variability in workload intensity. Policy Polit Nurs Pract 2007;8(1):7-19.

39. Engels JA, Landeweerd JA, Kant Y.An OWAS-based analysis of nurses' working postures. Ergonomics 1994;37(5):909-19.
40. Engels JA, van der Gulden JWJ, Senden TT, Hertog CAWM, Kolk JJ, Binkhorst RA. Physical workload and its assessment among nursing staff in nursing homes. J Occup Med 1994;36(3):338-45.

41. Chen J, Davis LS, Davis KG, Pan W, Daraiseh NM. Physiological and behavioural response patterns at work among hospital nurses. Nurs Manag 2011;19(1):57-68.

This work is available in Open Access model and licensed under a Creative Commons Attribution-NonCommercial 3.0 Poland License - http://creativecommons.org/ licenses/by-nc/3.0/pl/deed.en. 